to set their own prices. The Supreme Court would have to consider the possibility that courts in fair-trade jurisdictions might refuse to enforce their own laws because of the mail-order house's activities.

Before the Court arrives at a consideration of these last problems, it will have to be persuaded that a tort has been committed in a fair-trade jurisdiction; that the public policy of the non-fair-trade state is against fair-trade actions; and that enforcing the foreign fair-trade laws will in some sense subvert that public policy. Should the Court decide that the public policy of the forum bars the manufacturer's fair-trade action, the result will not be surprising. Congress has full power to legislate with regard to interstate commerce, but with fair trade it has chosen to abdicate that power to the states. It is not particularly shocking that the full faith and credit clause will not do what the commerce clause can do.

\title{
DAMAGES FOR THE WRONGFUL DEATH OF CHILDREN
}

The death of a child is the greatest of all losses-impossible of compensation-and yet at the same time an economic saving to the family involved. This situation poses a perplexing problem for our tort law by placing a great strain on the avowed principle that damages should be strictly compensatory in nature. Significant changes in the economic and social environment since the passage of Lord Campbell's Act in 1846 have made more acute the question whether substantial damages should be awarded for the wrongful death of a child. ${ }^{1}$ It is the purpose of this comment to indicate the difficulties involved in existing legal doctrines in the child death area, the economic factors affecting the "value" of the child to the family, and, finally, possible alternatives to present methods of compensation.

\section{I}

At common law there was no action for wrongful death. ${ }^{2}$ For various reasons this result was thought to be unsatisfactory ${ }^{3}$ consequently, statutes were

${ }^{1}$ The number of persons affected by this area of the law is indicated by the fact that 12,300 persons under twenty-four years of age died in 1952 in motor vehicle accidents alone where, in all probability, a large portion of the deaths would be actionable. National Safety Council, Accident Facts 59 (1953 ed.). In 1950, 22,453 persons under twenty-four years of age died from accidents of all types. Ibid., at 91 . See also Dublin, Health Progress 1936 to 1945, at 95 et seq. (1948).

${ }^{2}$ In "a civil court, the death of a human could not be complained of as an injury." Baker v. Bolton, 2 Rolle's Abridgement 575, placita 2 and 3 (1808). For a discussion of the common-law doctrine and early American cases, see Tiffany, Death by WrongfuI Act $\$ \$ 1-3,11$ (2d ed., 1913); Voss, The Recovery of Damages for Wrongful Death at Common Law, at Civil Law, and in Louisiana, 6 Tulane L. Rev. 201, 203 et seq. (1932).

${ }^{3}$ The main reason was the inequity of allowing recovery where plaintiff is almost killed but allowing no civil action where the wrongdoer commits the supposedly more serious offense of causing death. 
passed to remedy the situation. The earliest approach to the problem is represented by Lord Campbell's Act and similar statutes which create a cause of action for wrongful death to compensate "the families of persons killed by accidents." "The unanimous interpretation of these statutes is that they create a new cause of action wholly distinct from any causes of action that the decedent may have acquired during his lifetime. ${ }^{5}$ A second type of statute which does not create a new cause of action but preserves only those causes of action which have accrued to the decedent prior to his death has also been adopted in a number of states. ${ }^{6}$ It is doubtful whether the difference in type of statute has any significant effect on the practical results of the problem under consideration. This comment will be limited to a discussion of the measure of damages for the wrongful death of a child under the most common type of death statute, those modeled after Lord Campbell's Act. ${ }^{7}$

In enacting the Lord Campbell type of death statute, the legislatures have usually prescribed the measure of damages in general terms. Lord Campbell's Act, for example, provides that "in every such action the jury may give such damages as they may think proportioned to the injury resulting from such death. ..." In the leading case of Blake v. Midland Railway Company, ${ }^{\circ}$ this provision was interpreted to limit the award of damages to the probable

4Lord Campbell's Act, 9 \& 10 Vict., c. 93 (1846). The following year New York enacted the first American statute patterned after the English Act. N.Y.L. (1847) c. 450. Subsequently other states took similar action, using the English Act as a model. McCormick, Law of Damages $\$ 95$ (1935). Many state statutes set ceilings upon the damages recoverable. For a table showing these ceilings, consult Bouchelle, Removal of Limitations of Recoverable Amounts in Actions for Wrongful Death, 48 W. Va. L. Q. 255, 257 n. 4 (1942). Since Bouchelle's compilation, some states have raised the ceilings, e.g., IIl. Rev. Stat. (1953) c. $70, \$ 2(\$ 20,000)$; Minn. Rev. Stat. (1953) c. $573, \$ 573.02(\$ 17,500)$.

${ }^{8}$ Lord Campbell's Act "does not transfer this right of action to his [deceased's] representative, but gives to the representative a totally new right of action, on different principles." Blake v. Midland Ry. Co., [1852] 18 Q. B. 93, 110. Accord: In re Lister's Estate, 22 Ariz. 185, 195 Pac. 1113 (1921) ; Prouty v. City of Chicago, 250 Ill. 222, 95 N.E. 147 (1911); White v. Safe Dep. \& Tr. Co., 140 Md. 547, 118 Atl. 77 (1922); Kaczorowski v. Kalkosinske, $321 \mathrm{~Pa} .438,184$ Atl. 663 (1936).

- McCormick, Law of Damages $\$ 93$ (1935). Probably the earliest American survival statute was Conn. P.A. (1848) c. 5, $\$ 1$. The history of the Connecticut statute and its distinction from the Lord Campbell type of law are discussed in Shaker v. Shaker, 129 Conn. 518, 520, 29 A. 2d 765, 766 (1942). Consult also, for the distinction between the two types of statutes, Prosser, Law of Torts $\$ 103$ at 954 (1941). Under the survival type of statute, there can be no action where death is instantaneous because decedent had no time to suffer substantial damages; consequently, no action vested in him before death. Great Northern Ry. Co. v. Capital Trust Co., 242 U.S. 144 (1916).

${ }^{7}$ This comment will not consider the confusion arising because of the coexistence of both the Lord Campbell and survival types of statutes in the same jurisdiction. For able discussion of this problem, see Oppenheim, The Survival of Tort Actions and the Action for Wrongful Death-A Survey and a Proposal, 16 Tulane L. Rev. 386 (1942); Schumacher, Rights of Action under Death and Survival Statutes, 23 Mich. L. Rev. 114 (1924).

" 9 \& 10 Vict., c. 93 (1846).

[1852] 18 Q. B. 93. 
pecuniary loss to the beneficiaries ${ }^{10}$ resulting from the wrongful death. This interpretation has been followed under similar American statutes. ${ }^{11}$ Indeed, the statutes in a number of states provide explicitly that the award shall be for "pecuniary loss."12

The pecuniary-loss doctrine limits the recovery of the beneficiaries to the economic value of the deceased's contributions to the family and services performed for the family. ${ }^{13}$ There is no recovery for the emotional results of death, ${ }^{14}$ such as the loss of the deceased's society and companionship ${ }^{15}$ and

${ }^{10}$ Under this type of statute, the action is usually granted in favor of a personal representative or designated beneficiaries: e.g., Lord Campbell's Act, 9 \& 10 Vict., c. 93 (1846) (benefit of husband, wife, parent, or child) ; Ore. Rev. Stat. (1953) c. $30, \$ 30.010$ (gives father "an action for the injury or death of a child"). A few states name "heirs" or the "next of kin" as beneficiaries. A few other states name the estate of the decedent. It should be noted that in the latter states, compensation is for the prospective future net earnings or savings which the estate loses; in theory, this measure is slightly different from the probable-benefits-less-probable-costs measure discussed infra, but the normal practical results where close relatives are the beneficiaries would seem the same. Prosser, Law of Torts $\$ 103$ (1941).

II "In spite of these differences in phraseology [of the statutes], it is believed that the principles applicable to the measure of damages under all of these acts is generally the same, viz., that the damages are measured by the pecuniary loss resulting to the beneficiaries of the action from death." Tiffany, Death by Wrongful Act 323 (2d ed., 1913). The following are examples of typical provisions: Ariz. Code Ann. (1939) $\$ 31-101$ to 31-103 ("jury shall give such damages as they deem fair and just"); Idaho Code Ann. (1948) $\$ 5-310,5-311$ ("such damages may be given as under all the circumstances of the case may be just"); Md. Code Ann. (1951) art. 67, $\$ 1$ ("liable to an action for damages") ; Purd. Pa. Stat. Ann. (1953) Tit. 12, § 1601 ("damages").

${ }^{12}$ E.g., Ill. Rev. Stat. (1953) c. 70, 2 ("such damages as they shall deem a fair and just compensation with reference to pecuniary injuries"); Minn. Rev. Stat. (1953) c. 573, $\S 2$ ("such an amount as the jury may deem fair and just in reference to the pecuniary loss"); Ohio Rev. Code (Baldwin, 1953) Tit. 21, $\$ 2125.02$ ("jury may give such damages as it thinks proportioned to the pecuniary injury").

${ }^{13}$ E.g., Taylor v. Riggin, 40 Del. 149, 7 A. 2d 903 (1939); Hines v. Nichols, 76 Ind. App. 445, 130 N.E. 140 (1921) ; Frantz v. Gower, 119 Pa. Super. 156, 180 Atl. 716 (1935). Such items are the main ones. The concept occasionally contains less material harms, depending upon the beneficiary attempting to recover. Tiffany, Death by Wrongful Act $\$ 158$ (2d ed., 1913).

${ }^{14}$ E.g., St. Louis-San Francisco Ry. Co. v. Perryman, 213 Ark. 550, 211 S. W. 2d 547 (1948); Carrier v. Bornstein, 136 Me. 1, 1 A. 2d 219 (1938); Kalsow v. Grob, 61 N. D. 119,237 N. W. 848 (1931); Tiffany, Death by Wrongful Act $\$ 154$, n. 3 (2d ed., 1913). In Texas it is error to neglect giving the jury instructions that it cannot consider emotional harm. Internat'l \& G. N. R. Co. v. McVey, 99 Tex. 28, 87 S. W. 328 (1905) ; Hemsell v. Summers, 138 S. W. 2d 865 (Tex. Civ. App., 1940).

${ }^{15} 14$ A. L. R. 2d 498, $\$ 6$ (1950). In California, however, loss of comfort and society seems to be considered as part of the pecuniary loss and is compensable as long as it bears some reasonable relation to the other losses in the case. Fuentes v. Tucker, 31 Calif. 2d 1, 187 P. 2d 752 (1947) ; Barnett v. Garrison, 93 Calif. App. 2d 553, 209 P. 2d 426 (1949); Zeller v. Reid, 38 Calif. App. 2d 622, 101 P. 2d 730 (1940). A few other states have permitted recovery for this loss under typical statutes: Gardner v. Hobbs, 69 Idaho 288, 206 P. 2d 539 (1949); Aymond v. Western Union Tel. Co., 151 La. 183, 91 So. 671 (1922); Yazoo \& M. V. R. Co., v. Beasley, 158 Miss. 370, 130 So. 499 (1930); Van Cleave 
the mental pain and suffering of the beneficiaries. ${ }^{16}$ The limitation of recovery to pecuniary loss works relatively well where the deceased is old enough to have given clear indications of his pecuniary value to the beneficiaries. The past contributions or earnings of the deceased constitute a traditional and fairly reliable method of proof. Where the deceased is a young child, however, the doctrine of pecuniary loss is difficult of application, since few indications of his pecuniary value exist and his future is necessarily uncertain.

The initial difficulty of the pecuniary-loss doctrine is heightened by the fact that the costs of rearing the child during his remaining minority must be deducted from the total contributions of the child. ${ }^{17}$ These costs of upbringing are not only substantial but in the ordinary case may well exceed the value of the income and services reasonably expected from the child. ${ }^{18}$ If the costs of upbringing normally equal or exceed the expected pecuniary contribution of the child, nominal damages would be expected, since there can be no recovery for emotional loss. The facts, however, surprisingly indicate that substantial awards for the wrongful death of children are commonplace. For example, a study made by the New York Law Revision Commission, covering 171 litigated and compromised cases, found that awards for the wrongful death of minors in New York County during the years 1928 and 1933 ranged between $\$ 500$ and $\$ 5,000 .^{19}$ In the eleven cases prosecuted to judgment awards were slightly higher, ranging from $\$ 1,000$ to $\$ 7,500$. A similar study of thirteen cases, all of which were prosecuted to

v. Lynch, 109 Utah 149, 166 P. 2d 244 (1946) ; Anderson v. Hygeia Hotel Co., 92 Va. 687, 24 S. E. 269 (1896). Wis. Rev. Stat. (1951) $\$ 331.04$ (4) expressly authorizes recovery for loss of society and companionship not exceeding $\$ 2,500$.

${ }^{16} 14$ A. L. R. $2 d 485, \$ 5$ (1950). Contra: Robertson v. Jennings, 128 La. 795,55 So. 375 (1911); Anderson v. Hygeia Hotel Co., 92 Va. 687, 24 S. E. 269 (1896); Black v. Peerless Elite Laundry Co., 113 W. Va. 828, 169 S. E. 447 (1933). Fla. Stat. (1953) $\$ 768.03$ expressly provides for an award of "such sum for the mental pain and suffering of the parent (or both parents) if they survive, as the jury may assess." This award for mental anguish of the parents must bear a reasonable relation to the other damages in the case. Florida Dairies Co. v. Rogers, 119 Fla. 451, 161 So. 85 (1935).

${ }^{17} 14$ A. L. R. 2d 502, $\$ 8$ (1950). Georgia is an exception to this requirement of deduction of rearing costs. The Georgia statute gives damages for the full value of the deceased's life, defining such value as "the full value of the life of the decedent without deduction for necessary or other personal expenses of the decedent had he lived." Ga. Code Ann. (1935) $\$ 105-1308$. Georgia also has a special rule requiring that beneficiaries must show the child was capable of rendering valuable services before there can be recovery for the death. This requirement has been relaxed to some extent, however, by the decision that a child of two years was not incapable as a matter of law of rendering valuable services. Yarbrough v. Levinson Bros., 84 Ga. App. 131, 65 S. E. 2d 286 (1951).

${ }^{18}$ See part II infra.

\footnotetext{
${ }^{19}$ New York Law Revision Commission, 1935 Reports, Recommendations, and Studies 215 (1935).
} 
judgment in New York, shows an average award in excess of $\$ 3,500 .{ }^{20} \mathrm{~A}$ more recent compilation of cases from all jurisdictions shows that awards are now substantially higher than the earlier New York studies indicated. ${ }^{21}$

The existence of substantial damage awards in the child death situation permits two inferences: (1) that the pecuniary-loss doctrine is not applied with strictness and (2) that the mental anguish of the parents is considered by the jury in determining the amount of recovery. ${ }^{22}$ An examination of the cases demonstrates that both these inferences are well-founded.

Judicial treatment of two problems in the interpretation of "pecuniary loss"-- the temporal limits of prospective pecuniary loss and the proof necessary to show pecuniary loss-illustrates a tendency toward liberalization of the doctrine in the child death situation. An extension of the temporal period for which the value of the child's services are to be computed increases the amount of recovery. A majority of the courts now hold that the services and contributions reasonably expected from the minor both during the remaining period of minority and the entire period of majority should be considered. ${ }^{23}$ A minority of the courts limit consideration of benefits to those reasonably expected during the remaining minority upon the theory that possible benefits after majority are too speculative and that the father, normal beneficiary under many statutes, is legally entitled to the child's services and income only during minority. ${ }^{24}$

${ }^{20}$ Dublin \& Lotka, The Money Value of a Man 81, Table X-A (1st ed., 1930).

${ }^{21} 14$ A. L. R. 2d 550 (1950). In the cases noted not involving states allowing some type of emotional harm compensation or punitive damages, fourteen awards listed for children between fourteen and twenty-one years of age show a high of $\$ 10,000.00$, a low of $\$ 2,500.00$ and an average award of $\$ 5,753.66$. Ibid., at $\$ 5$. In similar cases for children between seven and fourteen years of age, thirteen awards listed show a high of $\$ 15,000.00$, a low of $\$ 1,000.00$ and an average of $\$ 5,523.84$. Ibid., at $\S 6$. In similar cases for children under seven years of age, twelve awards listed show a high of $\$ 7,500.00$, a low of $\$ 1,125.00$ and an average award of $\$ 4,364.95$. Ibid., at $\$ 7$. It should be noted that these cases are not a random sampling; all cases listed are situations where the award has been challenged as excessive and the court has specifically held the award not excessive.

${ }^{2}$ Consult Measure of Damages Recoverable by Parents-Wrongful Death of Infant, 2 Baylor L. Rev. 350 (1950). New York Law Revision Commission, 1935 Reports, Recommendations, and Studies 215, 216 (1935).

${ }^{\approx}$ McCormick, Law of Damages, $\$ 101$ at 354 (1935). Two factors probably operating on the courts to adopt this view in spite of its speculative consequences are that it affords an added reason for allowing recovery and that it takes into consideration notions of parental reliance in old age on children for support. Social Security laws operate to mitigate the force of the latter rationale.

${ }^{24}$ McCormick, Law of Damages $\S 101$ at 354 (1935). The minority view has long been under attack. Ibid. Maryland adopted the minority view at an early date. State v. B. \& O. R. Co., 24 Md. 84 (1866). A strong contention was made that passage of the Maryland Destitute Parents Act destroyed the rationale of the minority limitation. The Maryland court in State v. Cohen, 166 Md. 682, 172 Atl. 274 (1934), rejected this contention on the ground that the statute was largely penal in nature. The case is discussed in $30 \mathrm{Ill}$. L. Rev. 243 (1935). Cf. 14 A. L. R. 2d 510, \$11 (1950). 
Difficulties in the application of the pecuniary-loss doctrine to child death situations have contributed to a striking relaxation of proof requirements. It is virtually impossible in the case of young children to offer the type of evidence, such as past income and contributions to beneficiaries, which form the basis of awards for the death of older persons. In the early Washington case of Atrops v. Costello, ${ }^{25}$ the defendant argued that the plaintiff had established no special pecuniary losses and that the trial court's refusal of his offer to show probable costs of rearing the decedent was error. The court held that the plaintiff need show only such factors as "age of the child, her health, her habits, her character, and the station in life of her parents"26 to establish his case. It stated:

[W]e are satisfied that the great weight of authority sustains the doctrine that judgment can be obtained in the absence of proof of special pecuniary damage ... on the broad ground that proof of special damages is impracticable, and ... that calculations of this kind are within the special province of the jury. . . .27

The court went on to hold, however, that the exclusion of the defendant's offered proof was error: the defendant should not be precluded from affirmatively showing that no damages could arise from the death by introducing testimony as to the intention of the parents to keep the child in school, the costs of such schooling, the costs of maintenance, and the improbability of earnings.

In the later Washington case of Atkeson v. Jackson Estate ${ }^{28}$ involving the death of a two-year-old girl in good health whose parents could afford and intended to educate her at least through high school, the defendant introduced testimony indicating probable costs of rearing. He reasoned on appeal that since only the value of services up to the attainment of majority (age eighteen for girls) could be considered in Washington and since statistics showed that the average age of girls graduating from high school in Washington was eighteen and that earnings during the education period were small, the cost of maintenance until majority must of necessity exceed her probable earning capacity. The court rejected this argument on the grounds that a misfortune might befall the family forcing the girl to quit school in order to work and that:

in principle ... [the cases] hold that it is the purpose and intent of the statutes to provide for the award to the parents of substantial damages in all cases where the death of their child is caused by the negligence of another. ${ }^{20}$

A substantial recovery was upheld.

\footnotetext{
${ }^{2} 8$ Wash. 149, 35 Pac. 620 (1894).

${ }^{28}$ Ibid., at 154,621 .
}

${ }^{27}$ Ibid. Other early leading cases holding that no specific proof of pecuniary loss is necessary for recovery are Vicksburg v. McLain, 67 Miss. 4 (1889), and Thl v. 42d St., etc. R. R. Co., 47 N.Y. 317 (1872).

$\$ 72$ Wash. 233, 130 Pac. 102 (1913).

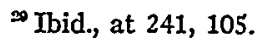


By 1943 it was absolutely clear that the defendant's right to show expected costs in excess of expected benefits had been rendered completely ineffective. In Skeels v. Davidson, ${ }^{30}$ a case involving the death of a physically and mentally subnormal boy who had been in constant need of expensive care, the court explicitly recognized the persuasiveness of the defendant's argument:

It is argued, and with good reason, that, by any conceivable pecuniary standard, the child was definitely shown to be a liability....31

After referring to the difficulties of the probable-benefits-less-probable-costs measure of damages, the court specifically retained and reaffirmed the pecuniary-loss doctrine for lack of alternatives. Nevertheless, the court sustained a verdict of $\$ 1,125$, saying:

[T] his court has long been committed to the majority rule that a jury may allow the plaintiff parent substantial, as distinguished from nominal, damages, upon the bare finding that his child's death was caused by another's negligence. ${ }^{32}$

The court did not attempt to reconcile its specific reaffirmation of the probable-benefits-less-probable-costs doctrine as a proper instruction for the jury and its affirmance of a substantial award even though the evidence showed that probable costs exceeded probable benefits. ${ }^{33}$

In accord with the views of the Washington court, the doctrine has been widely accepted that a sufficient case is established in child death actions by a showing of such factors as the decedent's physical and mental condition, age, sex, and friendliness toward parents, as well as various circumstances concerning the beneficiaries such as their life expectancy, health and financial

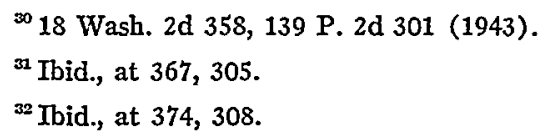

${ }^{33}$ Other courts, while condoning the probable-benefits-less-probable-costs measure of damages, have reversed low awards made by the jury or have held that more than nominal damages must be awarded as a matter of law. Wallace v. City of Rock Island, 323 IIl. App. 639, 56 N.E. 2d 636 (1944), holding an award of $\$ 500$ for the death of a thirteen-year-old boy inadequate because it was merely a nominal award; Morris v. Metropolitan St. Ry. Co., 64 N.Y. Supp. 878 (App. Div., 1st Dep't, 1900), holding that lack of specific proof of pecuniary loss does not justify awarding only six cents damages for the death of a sixteen-year-old-child; Gablas v. Jones, 262 App. Div. 794, 27 N. Y. S. 2d 314 (3d Dep't, 1941), holding an award of $\$ 1,000$ for the death of an eight-year-old infant inadequate by $\$ 2,500$ in a case where burial expenses exceeded $\$ 400$; Fabel v. Fazlett, $157 \mathrm{~Pa}$. Super. 416, $43 \mathrm{~A}$. 2d 373 (1945), holding verdicts of $\$ 500.00$ to the administrator and $\$ 272.50$ to parents inadequate for the death of an eleven-year-old child. In Thompson v. Town of Ft. Branch, 204 Ind. 152, 178 N.E. 440 (1932), the jury evidently followed the court's instructions about deducting costs of rearing the deceased. Funeral expenses of $\$ 400$ were shown and were recoverable under the statute. The jury awarded $\$ 1.00$. The court held that the funeral expense was a separate item and that "no rule of damages has been recognized in this state which would permit a defendant to reduce the amount of recovery for funeral expenses with an estimated excess of cost of maintenance over value of services." Ibid., at 164, 444. 
circumstances. ${ }^{34}$ Many states buttress this laxity of proof by a judicial presumption that parents suffer substantial pecuniary loss from the wrongful death of their child..$^{35}$ The courts, presumably in reliance upon a supposed policy of the death statutes to award substantial damages, have thus overcome the difficulties of the pecuniary-loss doctrine by delegating the task of computation to the discretion of the jury and by relying upon the policy of the death statutes to award substantial damages.

The death of a child is an inestimable loss; any jury can recognize that substantial harm has been caused by the child's death. Yet it is doubtful whether the application of the pecuniary-loss doctrine justifies the substantial damages awarded in most cases. The following analysis of child benefits and expenses suggests that the death of a child causes little or no economic harm to the family in the usual case, strengthening the inference that the mental anguish of the parents is considered by the jury in determining the amount of recovery.

II

Awards of substantial damages under the pecuniary-loss doctrine for the death of minors have become much more speculative and unreasonable than such awards were at the time the doctrine was initiated. Economic and social trends have reduced the value of earnings and services of large groups of minors and increased the cost of rearing children.

In the 1800's a much larger percentage of labor was involved in agricultural production and children made very significant labor contributions to the family farm. ${ }^{36}$ Moreover, employment of children eight years old and above was very common. ${ }^{37}$ Large portions of the minor population were

${ }^{34}$ E.g., Miller v. Hotel Savoy Co., 228 Mo. App. 463, 68 S.W. 2d 929 (1934); Kurn v. Youngblood, 193 Okla. 299, 142 P. $2 d 983$ (1943); Gill v. Laquerre, 51 R.I. 158, 152 Atl. 795 (1931); cases cited notes 27-33 supra.

${ }^{35}$ Carrier v. Bornstein, 136 Me. 1, 1 A. 2d 219 (1938); Karr v. Sixt, 146 Ohio 527, 67 N.E. 2d 331 (1946); Hodkinson v. Parker, 70 S.D. 272, 16 N.W. $2 d 924$ (1944). Contra: Wilson v. Consolidated Dressed Beef Co., $295 \mathrm{~Pa}$. 168, 145 Atl. 81 (1929). In some states this presumption does not extend to collateral relatives: C. P. \& St. L. R. Co. v. Woolridge, 174 Ill. 330,51 N.E. 701 (1898).

${ }^{36}$ David, Postwar Youth Employment 37, figure 6 (1943), shows a shift in percentage of total employed workers from sixty-five per cent engaged in agriculture during 1850 to twenty per cent in 1940. Moreover, large migrations of youth from farm to urban areas are still occurring. Ibid., at 113. Most of the statistics in this part of the comment are based on Census figures. In considering these figures the Census definition of employment should be borne in mind: a person is considered employed if he does any work for pay or profit, if he works without pay for fifteen or more hours a week in a family business or on a family farm, or if he is temporarily absent from a job due to strike, sickness, etc. U.S. Bureau of the Census, U.S. Census of Population: 1950 Vol. II, Characteristics of the Population, Part I, U.S. Summary (1953). "Labor force" includes persons employed, unemployed, or in the armed forces. Tbid.

${ }^{57}$ Folkes, Changes and Trends in Child Labor and Its Control 5 (1938). 
thus wage earners in a real sense, rendering pecuniary benefits susceptible to proof in court.

In the century since the passage of Lord Campbell's Act various factors have decreased child employment significantly: the public attitude toward the gainful employment of young children has changed to one of condemnation; a rising standard of living has reduced parental dependence upon childrens' earnings; and an increasing humanitarian interest in child welfare has influenced employers and parents to keep children out of the labor market. ${ }^{38}$ These factors have not only tended to decrease child employment but have also led to the passage of widespread state child-labor and compulsory school attendance laws. ${ }^{39}$ The child-labor laws generally provide a minimum age, usually at least fourteen, below which employment is prohibited in most types of work, and certification, supervision, and hours requirements for older youths permitted to work. ${ }^{40}$ The school laws generally require full-time school attendance until a specified age, usually at least sixteen. ${ }^{41}$ These factors have eliminated children below the age of sixteen almost entirely from the labor force. ${ }^{42}$ Young people over the age of sixteen have also left the labor force in large numbers, although a significant portion of that age-group is still gainfully employed. ${ }^{43}$ Many of these employed youths, however, are parttime, summer, or family workers whose earnings are relatively small. ${ }^{44}$ Indications of the average earnings for gainfully employed minors are difficult

${ }^{3 s}$ David, Barriers to Youth Employment 49-52 (1942).

${ }^{39}$ For an extensive compilation of these state laws consult State Child Labor Standards, Bulletin N. 158, Combined Publications of U.S. Dep't of Labor and Bureau of Labor Standards (1952).

${ }^{2}$ Authorities cited notes 38 and 39 supra.

${ }^{42}$ Authorities cited notes 38 and 39 supra. School attendance has consequently increased to ninety per cent of the population fourteen and fifteen years of age in 1940. David, Postwar Youth Employment 54, table 2 (1943). See also, for attendance figures, National Child Labor Committee, Child Labor after Ten Years of Federal Regulation 9 et seq. (1948); National Child Labor Committee, Trends in Employment of Young Workers 9 (1949).

"David, Postwar Youth Employment 52 et seq. (1943), shows that six and three per cent of the boys and girls, respectively, from ten to fifteen years of age inclusive were employed in 1930. Consult also Folkes, Changes and Trends in Child Labor and Its Control 7 (1938); National Child Labor Committee, Children and Youth at Work in 1951 (1951).

${ }^{43}$ Authorities cited note 42 supra. The 1950 Census shows that thirty-one per cent of the persons in the fourteen to nineteen-year-old age-group were members of the labor force. U.S. Bureau of the Census, U.S. Census of Population: 1950 Vol. II, Characteristics of the Population, Part 1: U.S. Summary 1-247, Table 118. The total percentage of males in the labor force by single years of age ranges from 13.2 per cent for fourteen-year-old youths to 78.4 per cent for twenty-year-olds. The corresponding figures for females are 4.1 per cent of the fourteen-year-olds and 47 per cent of the twenty-year-olds. Ibid., at Table 119.

"National Child Labor Committee, Trends in Employment of Young Workers 3 et seq. (1949). Youths seeking work are faced with a lack of jobs. Ibid. 
to obtain since such earnings vary according to the social status, age, color, education, geographic location and occupation involved.45 However, on the basis of the 1935 price level, it would seem that employed minors rarely earn more than a total of $\$ 5,000$ by the time they reach twenty-one. ${ }^{46}$ Most children probably earn much less. According to the 1950 Census which uses current price levels, the median income for all persons in the age-group from fourteen to nineteen years of age who are actually employed is only $\$ 429$ per year. ${ }^{47}$ In evaluating the effect these figures should have on awards, it must be noted that the pecuniary-loss doctrine deals only with the loss of the pecuniary value which would be reasonably expected to flow from the minor to the beneficiaries; in all probability, most of the child's earnings are really not contributed to the statutory beneficiaries but rather are spent for "extras" which the child wishes for himself.

Likewise, the value of services and benefits rendered in the household is difficult to ascertain. It is certain, however, that they are usually intermittent and of nebulous economic value. Consequently, some courts refuse to admit evidence concerning such services. ${ }^{48}$ It is doubtful that the value of such services justifies the award of a substantial amount in excess of actual lost income.

Costs of raising children have increased as the income and services of minors have decreased. The family has gradually become less of a self-sustaining production unit, buying services and products on the market which once it performed or produced for itself, thus increasing the family expenses allocable to the children.

The principal expenditures incurred in rearing a child to the age of eighteen have been estimated on the basis of $1935-36$ price levels. The total of these expenditures for families with an annual income of $\$ 2,500$ is $\$ 7,776$; the corresponding total for families with an annual income of from $\$ 5,000$ to $\$ 10,000$ is $\$ 16,337 .^{40}$ Interpolating from these statistics, an additional cost of approximately $\$ 1,500$ and $\$ 3,000$ respectively will be incurred in the remaining three years of minority. This would indicate that the total cost to the age of twenty-one is approximately $\$ 9,000$ to $\$ 20,000$ or above, depending on the family income level. ${ }^{50}$

${ }^{4}$ Consult U.S. Bureau of the Census, U.S. Census of Population: 1950 Vol. II, Characteristics of the Population, Part 1: U.S. Summary 1-300, Table 139 for variations in median income according to the classifications of color, sex, and urban-rural location in the age-group of fourteen to nineteen years.

${ }^{4}$ Dublin \& Lotka, The Money Value of a Man 65 (Rev, ed., 1946).

${ }^{87}$ Authority cited note 45 supra.

${ }^{2}$ St. Louis B. \& M. R. Co. v. Watkins, 245 S.W. 794 (Tex. Civ. App., 1903).

${ }^{\circ}$ Dublin \& Lotka, The Money Value of a Man 55, Table 14 (Rev. ed., 1946).

${ }^{\text {so }}$ It should be noted that expenses per year increase generally with age; consequently a proportionally larger part of the total cost would be incurred each year during the later years of minority involved in all minor death cases. Ibid. 
The available income and expense statistics concerning minors lead, therefore, to one conclusion: the costs of rearing a child during his remaining minority, whether that be a short period or a longer one, are likely to exceed the pecuniary benefits to be expected from the child.

\section{III}

The bereaved parents of a dead child are presumably compensated in our society only for the economic loss resulting from the wrongful death. In actuality, there is little doubt that it is an emotional harm rather than a pecuniary harm which is recognized by a jury awarding substantial damages for the wrongful death of a child. The retention of the pecuniary-loss doctrine on a verbal level would appear to be a pretense which could now be terminated. State legislatures might well consider the alternatives: (1) awarding only nominal damages unless economic loss is affirmatively established, or (2) explicitly recognizing emotional harm as a basis for substantial damages.

Continental law has generally taken the first alternative. Recovery has been denied in most cases because of the speculative nature of compensation. Only where specific proof of economic loss can be shown is recovery permitted; emotional harm is non-compensable. ${ }^{\text {51 }}$ The continental requirement of specific proof implicitly recognizes that there is little or no economic loss in the large majority of child death cases.

The explicit recognition of emotional harm as a basis for compensation is viewed with extreme reluctance by many courts and commentators. Thoughtful critics, such as Professor Jaffe, have urged that there be no extension of damages based on emotional harms. ${ }^{52}$ Two major policy reasons for this view are concern regarding proof of the causal connection between the defendant's action and the plaintiff's emotional harm, and a fear that the courts will be deluged with spurious claims of emotional harm. ${ }^{53}$ These fears have led to such doctrines as the "impact" rule, which supposedly guarantees

a1 At German law the parents can recover damages for the death of a child under B. G. B. $\$ \$ 823,844,845$ (German Civil Code). For recovery, they are required to show specific economic harm, e.g., funeral expenses or the lost services the deceased was bound by law to render. Reichsgerichtsräte-Kommentar $\$ \$ 844$ n. 1, 845 n. 3 (Berlin, 10th ed., 1953) ; Palandt, Bürgerliches Gesetzbuch $\$ \S 844$ n. 1, 1845 n. 3 (Munich and Berlin, 11th ed., 1953). Since compensation in money cannot be demanded for damages to interests not connected with property, German law generally allows no recovery for emotional harm. B. G. B. $\$ 253$. There are only two exceptions to this rule: damages for pain suffered from a "delict" by the injured party himself (B. G. B. $\$ 847$ ); damages for defloration in case of breach of promise to marry (B. G. B. $\$ 1300$ ). Consult, EnneccerusLehmann, Recht der Schrildverhältnisse 87 (Tübingen, 13th ed., 1950).

${ }^{52}$ Jaffe, Damages for Personal Injury: The Impact of Insurance, 18 Law \& Contemp. Prob. 219 (1953).

${ }^{53}$ For an extensive discussion of emotional harm and the underlying reasons for court attitudes toward it, see Smith, Relation of Emotions to Injury and Disease-Legal Liability for Psychic Stimuli, 30 Va. L. Rev. 193 (1944). 
both the causal link and the genuineness of emotional distress. ${ }^{54} \mathrm{~A}$ few courts, however, have permitted recovery for the negligent or intentional infliction of emotional harm in situations containing an inherent assurance of causation and genuineness. ${ }^{55}$ The child death situations afford such inherent assurances, at least as to members of the immediate family of the child. Sincere grief is a natural and almost universal incident of the death of a child.

The peculiar distinguishing characteristic of the child death situation, therefore, is the combination of inestimable grief and minor or negative pecuniary loss. To compensate for the former under the pretense of compensating for the latter is to engage in fictions. It is true that the emotional loss suffered by the parents is incalculable in nature, but so is the uncertain future of a child. The objection of incalculability, moreover, is an argument for nominal or arbitrary damage awards for both types of harm. And if one must choose between two incalculable harms, it would seem the wiser policy to choose the harm actually present in the majority of fact situations rather than that which is usually non-existent.

The main doctrinal challenge to the recognition of emotional harm lies not in its incalculability but rather in the function that money compensation serves in reference to such harm:

To say that grief and mental agony incident to the wrongful death of my child can be allayed by payment of money is meaningless nonsense. . . .56

Money cannot, of course, cure emotional harm with the same completeness as economic harm. Yet dollar compensation remains one of the few modes presently available to society by which to recompense harms. Society has utilized this mode of recognition in dealing with emotionally based harms in other areas of the law. ${ }^{57}$ Moreover, substantial awards have a deterrent function, cautioning prospective defendants to be careful or pay the consequences. Thus, although money cannot completely allay grief, it has some functional utility in reference to emotional harm and would, at the least, be a frank recognition of the actual harm suffered.

If the psychic harm involved in the wrongful death of a minor should be compensable, the problem of actual computation of damages remains. To measure subjectively the emotional harm suffered by the plaintiffs is probably beyond the scope of present psychological knowledge, constituting an

\footnotetext{
"For a discussion of the "impact" rule, see Prosser, Law of Torts 214 (1941).

"E.g., recovery granted for negligent non-delivery of a telegraphic death message causing mental anguish to close relative of deceased. Western Union Tel. Co. v. Redding, 100 Fla. 495,139 So. 743 (1930), noted in 7 N. Y. U. L. Q. Rev. 772 (1930). Intentional infliction of anguish by committing suicide in plaintiff's house held actionable. Blakely v. Shortal's Estate, 20 N.W. 2d 28 (S. Ct., Iowa, 1945), noted in 24 Tex. L. Rev. 214 (1946).

${ }^{s s}$ Florida Dairies Co. v. Rogers, 119 Fla. 451, 459, 161 So. 85, 88 (1935).

or Materials cited notes $52-55$ supra.
} 
even more difficult task than the actual proof of economic loss. An attempt objectively to measure the emotional harm, examining such factors as the age of the child, the number of surviving children in the family, religious outlooks, and the varying values placed on family-child bonds by different strata of society would constitute an equally impossible task.

An arbitrary but substantial measure of damages would be perhaps the best solution. Such an award might be a fixed amount or a scale within which the jury could fix damages. At the same time it would be wise to continue the recognition of actual economic harm. This could be done by a statutory provision requiring specific proof of economic loss. In a relatively small percentage of cases some economic harm is undoubtedly involved and could be proved. Children killed near the end of minority are often established in jobs and have given clear indications of contributions to the family. Moreover, in exceptional cases, such as a young child employed in the amusement world, indications of contributions and income are established at a relatively early age and are capable of proof.

The suggested solution would compensate for whatever harm has occurred. Where economic and emotional harms exist together, both would be utilized in computing damages. Where, perhaps in the majority of cases, only emotional harm exists, recovery would be allowed for it alone. Such a solution would honestly deal with the actual harm involved, without straining the pecuniary-loss doctrine to fit situations where no pecuniary loss has occurred. Broader societal effects of the recognition of emotional harm would be minimized because the recovery, although substantial, would have an arbitrary ceiling. The aphorism that it is cheaper to kill a child than to kill an adult would retain its paradoxical sting of truth, yet the candid recognition of real emotional harm in the child death situation by an award of substantial, though limited, damages would constitute a more civilized solution to a perplexing damage problem.

\section{INTERPLAY BETWEEN STATE DIRECT ACTION STATUTE AND FEDERAL ADMIRALTY LAW: ANOTHER SOLUTION TO THE CUSHING CASE}

Marine insurance is subject to the legislative control of both the federal government and the state where the contract is written. ${ }^{1}$ While the subject matter of the contract-the liability of an owner of a vessel-falls within

\footnotetext{
${ }^{1}$ Insurance Co. v. Dunham, 11 Wall. (U.S.) 1 (1870), established the jurisdiction of a federal court sitting in admiralty over recovery on a policy of ocean marine insurance. The case contains a discussion of the origins of ocean marine insurance and admiralty proceedings. Concerning a state's legislative powers over marine insurance see Hooper v. California, 155 U.S. 648 (1894).
} 